\title{
Enhancing student teacher self-efficacy beliefs to teach priority learners in New Zealand
}

\author{
Sally Hansen, Alison Sewell, Sarojinie Fernando, Abdelhamid Safa \\ Institute of Education, College of Humanities and Social Sciences, Massey University, \\ New Zealand
}

The aim of this study was to explore the changes in student teacher efficacy beliefs for teaching priority learners over the course of a one-year postgraduate initial teacher education programme. The sample comprised 23 participants enrolled in the 2015 cohort in a pilot initial teacher education programme specifically tailored to enhance student teacher expertise to teach priority learners. Participants completed a specially designed and refined self-efficacy scale - Self-Efficacy with Diverse Learners: Student Teacher Scale - that targeted their efficacy beliefs about successfully promoting learning for priority learners at the start and at the end of their programme. Changes in efficacy beliefs were statistically measured and the findings indicated that student teacher efficacy beliefs for teaching priority learners had improved significantly over the course of their teacher education programme. In particular, the findings showed that their reported efficacy beliefs for implementing strategies for teaching English speakers of other languages, students with low socioeconomic status, and Māori learners had nearly doubled. Such findings have significant implications for teacher education reforms that aim to enhance student teacher adaptive expertise and in so doing, assist with the long-term goal of achieving more equitable educational outcomes in New Zealand.

Keywords: self-efficacy, student teachers, initial teacher education, teacher preparation, priority learners

\section{Introduction}

A major challenge facing education in New Zealand is the continuing disparities of educational outcomes for particular groups of learners (Bishop, Berryman, Cavangh, \& Teddy, 2009; Connor, 2013; Education Review Office, 2012; Organisation for Economic Co-operation and Development, 2015). These disparities are becoming more complex and more significant against a landscape of dynamic change. As recently as July 2017, the New Zealand Education Council released a discussion paper that reinforced the increasing demands and expectations of teachers in relation to such change:

The increased level of expectations for teachers to make a difference ... the diversity of learners ... and the wider changes in work and society, have raised the requirements of teachers as practicing professionals. In short, the challenge of being a teacher is more complex than previously understood, and ITE should reflect this. (p. 1)

The term priority learners is defined by the Education Review Office (2012) as "groups of students who have been identified as historically not experiencing success in the New Zealand schooling system. These include Māori and Pacific learners, those from low socio-economic 
backgrounds, and students with special education needs" (p. 4). In light of these sustained educational inequities, the challenge has never been greater to sufficiently prepare teachers to support more equitable learning outcomes in our increasingly diverse student populations (Florian, 2009; Kaur, 2012), particularly for those learners currently not succeeding in the education system.

In order to address this challenge, the design of initial teacher education programmes needs to "change dramatically if they are to succeed at preparing $21^{\text {st }}$ century teachers who can work effectively with all students, particularly those traditionally marginalized by the education system" (Cochran-Smith et al., 2016, p. 68). An important part of meeting this challenge is to enhance teachers' sense of efficacy for developing the adaptive expertise to teach all learners.

The Quality Teaching Agenda (Ministry of Education, 2013a) was designed to strengthen the capability of the schooling workforce. New initial teacher education initiatives were developed and additional funding provided to improve the expertise of graduating teachers. One such initiative, which drew on findings from both New Zealand and international research, was to pilot a small number of exemplary postgraduate initial teacher education programmes to provide an evidence base about what works best in the provision of initial teacher education.

The study reported in this paper, to measure changes in student teachers' efficacy beliefs, is set within the context of one of the pilot exemplary initial teacher education programmes. Student teacher efficacy beliefs were assessed at programme entry and exit using the same scale. Item responses were then analysed to observe the changes over the year and to consider them in relation to the tailored design features of the programme.

\section{Literature review}

Over the past 40 years, Bandura $(1977 a, b, 1997)$ has claimed that people's judgments of their capabilities to carry out action in order to achieve certain goals has the greatest impact on shaping behaviour. A focal point of social-cognitive theory is this notion of self-efficacy. In an educational setting, teacher efficacy is seen as the extent to which a teacher feels confident that he/she can "bring about desired outcomes of student engagement and learning" (Tschannen-Moran \& Woolfolk Hoy, 2001, p. 783). Teacher efficacy is linked not only to a teacher's sense of confidence or certainty, but also to levels of resilience, qualities that have also been identified as being critical for effective teaching (Feiman-Nemser et al., 2001; Goddard, Hoy, \& Woolfolk Hoy, 2000). Teacher efficacy has also been strongly linked to students' learning and achievement, with some studies suggesting that teacher efficacy may be the most significant predictor of teacher influence on student achievement, as well as a contributor to it (Bandura, 1997; Ross, 1998; Tschannen-Moran \& Woolfolk Hoy, 1998, 2001). Therefore, within culturally diverse classroom settings, it is important to consider teachers' cultural self-efficacy, which Gibbs (2002) defines as: "teachers' sense of self-belief about their capability to function effectively within culturally-diverse settings" and to "effect action within culturally defined contexts in order to attain desired goals" (pp. 1 \& 3).

Bandura (1977b) emphasised two factors that motivate a person to act: 'outcome expectations' - an individual's assessment that certain actions will lead to desired outcomes;

and 'efficacy expectations' - an individual's belief that they can successfully produce the outcome. For teachers, it is critical that they have both positive outcome expectations and 
efficacy expectations. With reference to the current study, the outcome expectations refer to student teachers' view that high leverage and culturally-responsive pedagogies will positively impact their learners, and efficacy expectations are their beliefs that they can successfully enact these pedagogies in the dynamic context of the classroom. The distinction is therefore made between the student teacher believing that specific teaching actions will lead to worthwhile student learning outcomes and believing that they are capable of performing these actions.

Bandura's social cognitive theory shows that people use information from four sources in order to make judgments of their self-efficacy for a specific future-focused task. These efficacy sources, in order of influence, are: enactive mastery experiences; vicarious mastery experiences; social persuasion; and physiological-emotional symptoms. A student teacher who has a perception that $s /$ he has designed and implemented the teaching process successfully (mastery experience) will have raised expectations that $s /$ he will perform better in the future. On the other hand, if a student teacher believes that $s /$ he has been unsuccessful in teaching, levels of efficacy beliefs will be lower in future teaching. Vicarious experiences are the observations made of peers as they engage successfully in teaching. The third source is social persuasion, such as encouraging verbal feedback after a teaching performance given by a trusted stakeholder such as a mentor teacher or teacher educator. The last source of psychological states are interpretations of actual and perceived emotional states, such as feeling eager and excited to teach, or feeling anxious and fearful about the prospect of teaching.

The consequences of these four sources promoting self-efficacy are far-reaching for a student teacher. Those who are convinced of their competence to promote learning for priority learners will readily participate in the task of finding the right evidence-informed strategies or interventions and practise its enactment to adapt their expertise. Furthermore, they will set higher goals for both their own professional learning and their learners, remaining optimistic and persistent in the face of this extremely challenging task while experiencing a degree of eagerness to help. Student teachers with high levels of efficacy beliefs are more likely to utilise this arousal as a motivator to keep enhancing their future performance (Cinici, 2016).

Conversely, teachers with low self-efficacy tend to avoid the complex tasks of diagnosing learning needs, finding an evidence-informed intervention, and finding the impact of their changed practice on students' learning. Any attempts of this nature will not be sustained in the belief that the effort is either too great or that it exceeds their capabilities. Clearly, these two contrasting efficacy scenarios - willingness to tackle and persist at promoting learning, or shying away from the challenge and feeling poorly equipped to do so - will lead to two very different outcomes for priority learners. Self-efficacy is thus an important predictor of student teacher performance, particularly their ability to develop and adapt their pedagogical practices to promote achievement for priority learners. This efficacyaction-outcome association points to the importance of intentionally fostering self-efficacy in the initial teacher education learning situation - both at the university and in the classroom.

New teacher preparation initiatives have been launched worldwide with the aim of providing graduating teachers with the critical knowledge and adaptive expertise to teach diverse learners. The Education Workforce Advisory Group, established in 2008, identified how to raise the quality of teaching across the schooling sectors. This initiative aligned New Zealand with international providers of initial teacher education to develop and to trial exemplary postgraduate teaching qualifications "to build a teaching profession that can 
deliver the outcomes we want for all New Zealand students" (Tolley, 2010, n.p.). The work to lift the quality of initial teacher education began in 2013 with the provision of additional funding to trial a small number of exemplary postgraduate initial teacher education programmes with high entry standards and improved links between the provider, schools and the student teachers. The initial teacher education programme at the focus of this study began in 2015 - the second year of these pilot programmes.

One of the key challenges facing designers of these pilot programmes is to create learning environments/experiences/opportunities that enhance self-efficacy beliefs where student teachers can say with confidence: 'I am capable of succeeding' especially when faced with teaching a class of diverse learners. The literature reviewed above highlights the importance of creating learning experiences that enhance teacher efficacy that i) supports actual and vicarious success, ii) provides opportunities for social persuasion, and iii) enhances positive physiological responses and reduces negative ones. Initial teacher education programmes can build actual and vicarious success through making stronger theoretical and evidential links between course content and classroom practice. Indeed, the concern that course content did not always reflect current research about effective teaching was noted in the Workforce Advisory Group (Tolley, 2010). These theory-research-practice links can only be forged by developing and sustaining strong and enduring relationships between the university provider and the school or centre. This call for stronger connections was a significant theme of the Teacher Education Forum of Aotearoa New Zealand Conference in 2012. O'Neill, Hansen, Rawlins, and Donaldson (2013) argued that, 'the 'us' and 'them' mentality that has at times been the hallmark of relationships needs to be challenged, and replaced with relational models that are truly cooperative" (p. 3).

Another important means of promoting enactive and vicarious mastery experiences for student teachers is to prioritise their engagement in cycles of evidence-informed professional learning inquiry which enables them to base their practice on what is already known to work in other contexts (Timperley, 2011). Initial teacher education programmes can also provide opportunities for social persuasion through the provision of constructive and ongoing formative feedback in the clinical setting, at the university, and in digital learning environments. Finally, initial teacher education programmes need to reduce negative physiological responses and enhance positive ones through initiatives that build resilience and support student teachers to manage their physiological responses, particularly those that accompany teaching performance with priority learners.

\section{Context for this study}

The context for this study is a pilot Masters of Teaching and Learning (MTchgLn) initial teacher education programme for primary and secondary teachers. In response to the Ministry of Education's (2013a) tender, a team of university teacher educators and experienced teachers from local primary and secondary schools collaborated in the design and development of this programme. It was essentially designed as a local response to New Zealand's policy agenda to raise achievement. A key aim of the Masters of Teaching and Learning was to develop efficacious teachers with the adaptive expertise to respond confidently and resiliently to the challenges posed by each learner, but most especially by the priority learner groups that are most at risk of not achieving success. While raising student teacher efficacy with priority learners is challenging, a number of recent international studies point to certain initial teacher 
education design features that have enhanced their graduates' self-efficacy for teaching across the curriculum and for inclusive education. International studies were examined as part of the development process, and design elements were included that had indicated success in other similar jurisdictions.

The design elements of the 2015 Masters of Teaching and Learning programme are shown in Figure 1 below.

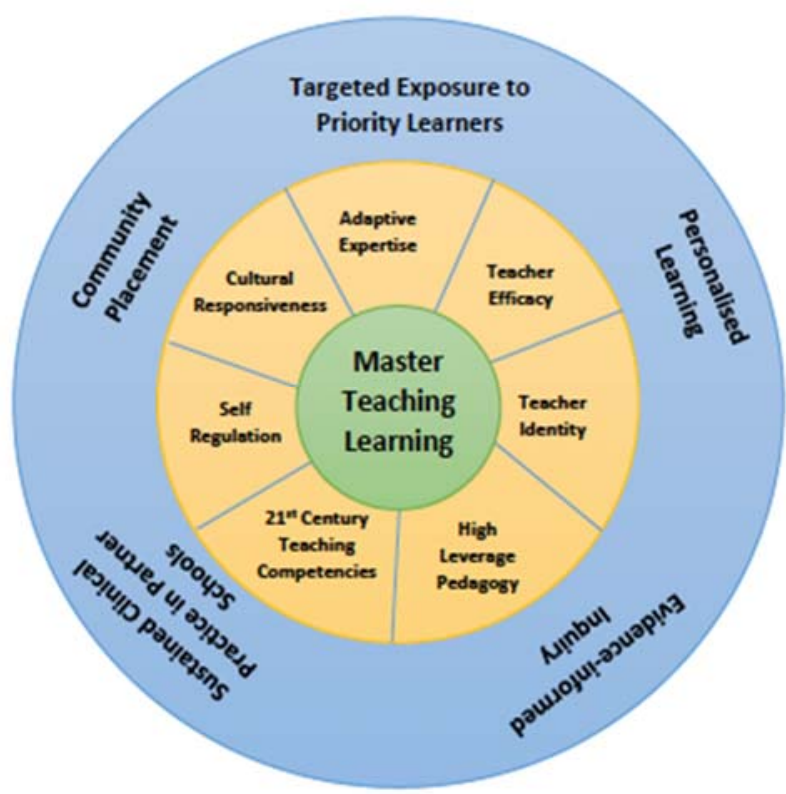

Figure 1. Distinctive design elements of Masters of Teaching and Learning programme

The distinctive design elements shown in Figure 1 identify the key principles (inner circle) and design innovations (outer circle) that are foundational to the Masters of Teaching and Learning programme. These principles and design innovations aim to promote the competencies as expressed in the programme's Graduate Profile. ${ }^{1}$ Five innovations were specifically designed to support student teachers to develop: adaptive expertise, cultural responsiveness, positive teacher-efficacy, a strong sense of identity, self-regulation, $21^{\text {st }}$ century teaching competencies, and ability to use high-leverage pedagogies:

1. Evidence-informed inquiry required student teachers to use evidence of their priority learners' needs, and evidence from research, to disrupt everyday practice through the targeted use and assessment of an intervention in successive inquiry cycles. This inquiry stance on teaching that is critical and transformative is linked to the high standards for the learning of all students as well as to teachers' professional learning (Cochran-Smith, 2003).

1 The professional competencies in The Graduating Teacher Standards, Tātaiako, The Effective Teaching Profile and The Code of Ethics for Registered Teachers were used to derive the MTchgLn programme's graduate profile. 
2. Targeted exposure to priority learners occurred in the sustained evidence-informed inquiry cycles in the clinical placement to focus attention on their specific yet diverse learning needs. Targeted exposure was also maintained through visits to up to six 'exemplary' schools to observe and critique their school-wide innovations to meet the learning needs of priority learners.

3. Sustained clinical practice in two partner schools created a 'third space' (Williams, 2014) partnership between the university-based teacher educators and school-based lead mentor teachers and mentor teachers to increase the clinical component where theory and research taught at the university could be enacted in a sustained clinical setting. Three days per week were spent during school terms enacting concepts and strategies, which were the concurrent focus of their course work.

4. Community placement provided a 20-hour service learning experience within a social and cultural group whose values and practices challenged their assumptions or frames of reference against which they currently made judgments of students and their whānau and communities. This provided an opportunity to develop a deeper understanding of diversity and inequity to inform their teaching practice.

5. Personalised learning opportunities were created to enable students to have more control of their learning and become more self-regulated. A triadic framework of supervisor, lead mentor teacher and mentor teacher was established to wrap specialist support around each student teacher, and ensure the development of identified skills and pedagogical content knowledge.

\section{The study}

This study used a longitudinal design comprising a single-group entry pre-test, intervention (participation in the initial teacher education programme), and exit post-test. The entry/exit survey method was specifically designed to measure changes in student teacher efficacy beliefs for teaching across a range of items (Hansen, Harworth, \& McLaughlin, in press).

\section{Participants}

The participants were from the first cohort (2015) of student teachers enrolled in the Masters of Teaching and Learning at a New Zealand university. Twenty seven primary and secondary candidates were enrolled in the programme at the start of the year, but only 25 completed the initial survey in March 2015. Two students withdrew through the year, leaving 23 who completed the programme. The sample ranged in age from $21-43$ with $85 \%$ female and $15 \%$ male. All candidates held an undergraduate degree with a minimum grade point average of $\mathrm{B}+$.

Completion of the survey was voluntary, with an invitation and information provided via the programme's online learning platform. The surveys were distributed at the conclusion of a class in March 2015 to all the students. The students had completed five weeks in the programme at this time. These same surveys were returned to them in December 2015 so that they could see their initial responses and make decisions about their self-efficacy rating at that time. 


\section{Method}

The-Self-Efficacy with Diverse Learners: Student Teacher Scale measure was developed during 2014 through a rigorous psychometric and refinement process by a team of university researchers (Hansen et al., in press) to specifically measure the self-efficacy beliefs of preservice teachers for teaching diverse learners. Each item in the scale was worded using a common stem of 'I am confident I can...'. For the purposes of this survey, the term diverse learners was used with the intention of being a little broader than the Ministry of Education's definition of priority learners. The scale was developed to be useful for all initial teacher education programmes, and as such it was considered that diverse learners was likely to be a more widely understood term by ITE candidates.

Based on recommendations from Bandura (2006), a 100-point Likert-like response scale was used to indicate the strength of pre-service teachers' efficacy beliefs, with units shown in intervals of 10 with descriptive anchors at 0 (not at all), 50 (moderately), and 100 (highly confident).

\section{Results}

Descriptive analyses were generated using the Statistical Package for the Social Sciences (SPSS) which presented a range of scores across the variables. Table 1 shows some comparison of responses between March and December 2015 of the complete data $(n=23)$. Overall, the item mean scores for all items in December are significantly higher than those in March.

Table 1

Scores across the variables*

\begin{tabular}{|c|c|c|c|c|c|c|c|c|c|}
\hline & \multicolumn{4}{|c|}{$\begin{array}{l}\text { March } 2015 \text { Complete } \\
\qquad(n=23)\end{array}$} & \multicolumn{4}{|c|}{$\begin{array}{l}\text { December } 2015 \text { Complete } \\
\qquad(n=23)\end{array}$} & \multirow[b]{2}{*}{$\begin{array}{c}\text { Mean } \\
\text { Difference }\end{array}$} \\
\hline & Min. & Max. & Mean & SD & Min. & Max. & Mean & SD & \\
\hline $\begin{array}{l}\text { 1. seek advice and guidance } \\
\text { about learners' cultural } \\
\text { backgrounds and values }\end{array}$ & 3 & 10 & 6.00 & 1.78 & 7 & 10 & 8.70 & 0.77 & 2.70 \\
\hline $\begin{array}{l}\text { 2. prepare adequately for } \\
\text { teaching diverse learners }\end{array}$ & 1 & 8 & 4.13 & 1.66 & 7 & 10 & 8.22 & 0.74 & 4.09 \\
\hline $\begin{array}{l}\text { 3. teach in order to enable all } \\
\text { children to consistently } \\
\text { experience success. }\end{array}$ & 2 & 8 & 4.26 & 1.48 & 7 & 10 & 8.17 & 0.65 & 3.91 \\
\hline $\begin{array}{l}\text { 4. take account of how my } \\
\text { background and values } \\
\text { influence my teaching }\end{array}$ & 5 & 10 & 6.68 & 1.21 & 7 & 10 & 9.09 & 0.79 & 2.41 \\
\hline $\begin{array}{l}\text { 5. maintain an environment } \\
\text { that is focused on learning }\end{array}$ & 2 & 10 & 6.00 & 1.41 & 7 & 10 & 8.87 & 0.69 & 2.87 \\
\hline $\begin{array}{l}\text { 6. implement strategies that } \\
\text { meet the needs of learners } \\
\text { in low socio-economic areas }\end{array}$ & 2 & 9 & 4.48 & 1.73 & 6 & 9 & 8.30 & 1.02 & 3.82 \\
\hline
\end{tabular}




\begin{tabular}{|c|c|c|c|c|c|c|c|c|c|}
\hline & \multicolumn{4}{|c|}{$\begin{array}{l}\text { March } 2015 \text { Complete } \\
\qquad(n=23)\end{array}$} & \multicolumn{4}{|c|}{$\begin{array}{l}\text { December } 2015 \text { Complete } \\
\qquad(n=23)\end{array}$} & \multirow[b]{2}{*}{$\begin{array}{c}\text { Mean } \\
\text { Difference }\end{array}$} \\
\hline & Min. & Max. & Mean & SD & Min. & Max. & Mean & SD & \\
\hline $\begin{array}{l}\text { 7. include positive, culturally } \\
\text { relevant images in my } \\
\text { teaching environment }\end{array}$ & 1 & 9 & 5.26 & 2.09 & 7 & 10 & 9.04 & 0.64 & 3.78 \\
\hline $\begin{array}{l}\text { 8. develop professional 'ethics } \\
\text { of care' with diverse } \\
\text { learners }\end{array}$ & 3 & 9 & 5.50 & 1.77 & 7 & 10 & 8.91 & 0.67 & 3.41 \\
\hline $\begin{array}{l}\text { 9. assist families to help their } \\
\text { children do well in school }\end{array}$ & 1 & 10 & 4.22 & 2.30 & 5 & 9 & 7.78 & 1.13 & 3.56 \\
\hline $\begin{array}{l}\text { 10. implement strategies that } \\
\text { meet the needs of Māori } \\
\text { learners }\end{array}$ & 2 & 9 & 4.74 & 1.63 & 8 & 9 & 8.74 & 0.45 & 4.00 \\
\hline $\begin{array}{l}\text { 11. build a sense of trust with } \\
\text { learners from all } \\
\text { backgrounds }\end{array}$ & 5 & 9 & 6.52 & 1.12 & 8 & 10 & 9.09 & 0.61 & 2.57 \\
\hline $\begin{array}{l}\text { 12. develop a sense of } \\
\text { community amongst } \\
\text { diverse learners }\end{array}$ & 3 & 9 & 5.87 & 1.60 & 8 & 10 & 8.86 & 0.66 & 2.99 \\
\hline $\begin{array}{l}\text { 13. provide feedback to } \\
\text { learners in culturally } \\
\text { relevant ways }\end{array}$ & 1 & 8 & 4.61 & 1.85 & 7 & 9 & 8.18 & 0.80 & 3.57 \\
\hline $\begin{array}{l}\text { 14. establish good relationships } \\
\text { with community groups } \\
\text { important to diverse } \\
\text { learners }\end{array}$ & 1 & 9 & 4.96 & 2.10 & 5 & 10 & 8.32 & 1.25 & 3.36 \\
\hline $\begin{array}{l}\text { 15. actively engage with } \\
\text { parents from diverse } \\
\text { backgrounds about their } \\
\text { child's progress }\end{array}$ & 2 & 8 & 4.87 & 1.71 & 4 & 9 & 7.77 & 1.15 & 2.90 \\
\hline $\begin{array}{l}\text { 16. provide challenging } \\
\text { activities for diverse } \\
\text { learners }\end{array}$ & 3 & 7 & 5.18 & 1.40 & 7 & 10 & 8.64 & 0.66 & 3.46 \\
\hline $\begin{array}{l}\text { 17. implement strategies that } \\
\text { meet the needs of learners } \\
\text { whose first language is not } \\
\text { English }\end{array}$ & 0 & 8 & 3.48 & 2.02 & 3 & 10 & 7.82 & 1.56 & 4.34 \\
\hline $\begin{array}{l}\text { 18. find meaningful ways to } \\
\text { celebrate the diversity of } \\
\text { learners }\end{array}$ & 2 & 8 & 5.04 & 1.55 & 3 & 10 & 8.41 & 1.40 & 3.37 \\
\hline $\begin{array}{l}\text { 19. facilitate the involvement of } \\
\text { interpreters where needed } \\
\text { to communicate with } \\
\text { linguistically diverse } \\
\text { students and their families }\end{array}$ & 0 & 8 & 4.74 & 2.07 & 5 & 9 & 7.75 & 1.07 & 3.01 \\
\hline $\begin{array}{l}\text { 20. identify appropriate } \\
\text { mentors to support me in } \\
\text { enhancing my practices } \\
\text { with diverse learners }\end{array}$ & 1 & 8 & 6.22 & 1.59 & 8 & 10 & 9.32 & 0.65 & 3.10 \\
\hline
\end{tabular}




\begin{tabular}{|c|c|c|c|c|c|c|c|c|c|}
\hline & \multicolumn{4}{|c|}{$\begin{array}{l}\text { March } 2015 \text { Complete } \\
\qquad(n=23)\end{array}$} & \multicolumn{4}{|c|}{$\begin{array}{l}\text { December } 2015 \text { Complete } \\
\text { ( } n=23)\end{array}$} & \multirow[b]{2}{*}{$\begin{array}{c}\text { Mean } \\
\text { Difference }\end{array}$} \\
\hline & Min. & Max. & Mean & SD & Min. & Max. & Mean & SD & \\
\hline $\begin{array}{l}\text { 21. build on the interests and } \\
\text { prior knowledge of diverse } \\
\text { learners to make learning } \\
\text { meaningful for them }\end{array}$ & 4 & 8 & 5.78 & 1.13 & 8 & 10 & 9.05 & 0.49 & 3.27 \\
\hline $\begin{array}{l}\text { 22. use appropriate role models } \\
\text { to improve my practice with } \\
\text { diverse learners }\end{array}$ & 2 & 9 & 6.17 & 1.53 & 9 & 10 & 9.14 & 0.35 & 2.97 \\
\hline $\begin{array}{l}\text { 23. assess students' } \\
\text { understanding and } \\
\text { knowledge using a range of } \\
\text { culturally relevant methods }\end{array}$ & 1 & 8 & 3.87 & 1.71 & 6 & 9 & 8.04 & 0.77 & 4.17 \\
\hline $\begin{array}{l}\text { 24. openly discuss with } \\
\text { professional colleagues } \\
\text { challenges in supporting } \\
\text { diverse learners }\end{array}$ & 5 & 9 & 6.74 & 1.14 & 8 & 10 & 9.17 & 0.58 & 2.43 \\
\hline $\begin{array}{l}\text { 25. interact with learners in a } \\
\text { range of relevant languages }\end{array}$ & 0 & 8 & 2.86 & 2.27 & 1 & 9 & 6.77 & 1.95 & 3.91 \\
\hline $\begin{array}{l}\text { 26. try innovative strategies in } \\
\text { my practice with diverse } \\
\text { learners }\end{array}$ & 1 & 9 & 5.09 & 1.95 & 8 & 10 & 8.61 & 0.66 & 3.52 \\
\hline $\begin{array}{l}\text { 27. implement strategies that } \\
\text { meet the needs of culturally } \\
\text { diverse learners }\end{array}$ & 1 & 8 & 4.30 & 1.87 & 7 & 10 & 8.52 & 0.67 & 4.22 \\
\hline $\begin{array}{l}\text { 28. be sensitive to factors in } \\
\text { children's lives that may } \\
\text { affect their learning }\end{array}$ & 3 & 10 & 6.39 & 1.78 & 7 & 10 & 9.09 & 0.67 & 2.70 \\
\hline $\begin{array}{l}\text { 29. seek opportunities to } \\
\text { support learners from } \\
\text { diverse cultures. }\end{array}$ & 1 & 10 & 5.52 & 1.88 & 7 & 10 & 8.83 & 0.72 & 3.31 \\
\hline $\begin{array}{l}\text { 30. establish and maintain high } \\
\text { expectations for diverse } \\
\text { learners }\end{array}$ & 3 & 10 & 6.14 & 1.73 & 8 & 10 & 9.22 & 0.67 & 3.08 \\
\hline
\end{tabular}

*Survey scale: $0=$ not at all, $5=$ moderately, $10=$ highly certain

Table 2

Comparison of responses between March and December 2015*

\begin{tabular}{|c|c|c|c|c|c|c|c|c|}
\hline & \multicolumn{4}{|c|}{$\begin{array}{l}\text { March } 2015 \text { Complete } \\
\qquad(n=23)\end{array}$} & \multicolumn{4}{|c|}{$\begin{array}{l}\text { December } 2015 \text { Complete } \\
\qquad(n=23)\end{array}$} \\
\hline & Min. & Max. & Mean & SD & Min. & Max. & Mean & SD \\
\hline Sum Score & 98 & 249 & 154.48 & 35.47 & 153 & 275 & 251.00 & 24.43 \\
\hline Mean & 3.38 & 8.30 & 5.18 & 1.17 & 7.43 & 9.17 & 8.55 & 0.38 \\
\hline
\end{tabular}

*Survey scale sum scores: 0 = not at all, $150=$ moderately, $300=$ highly certain. 
Figure 2 below depicts the mean standard scores for all survey results in March and December, 2015.

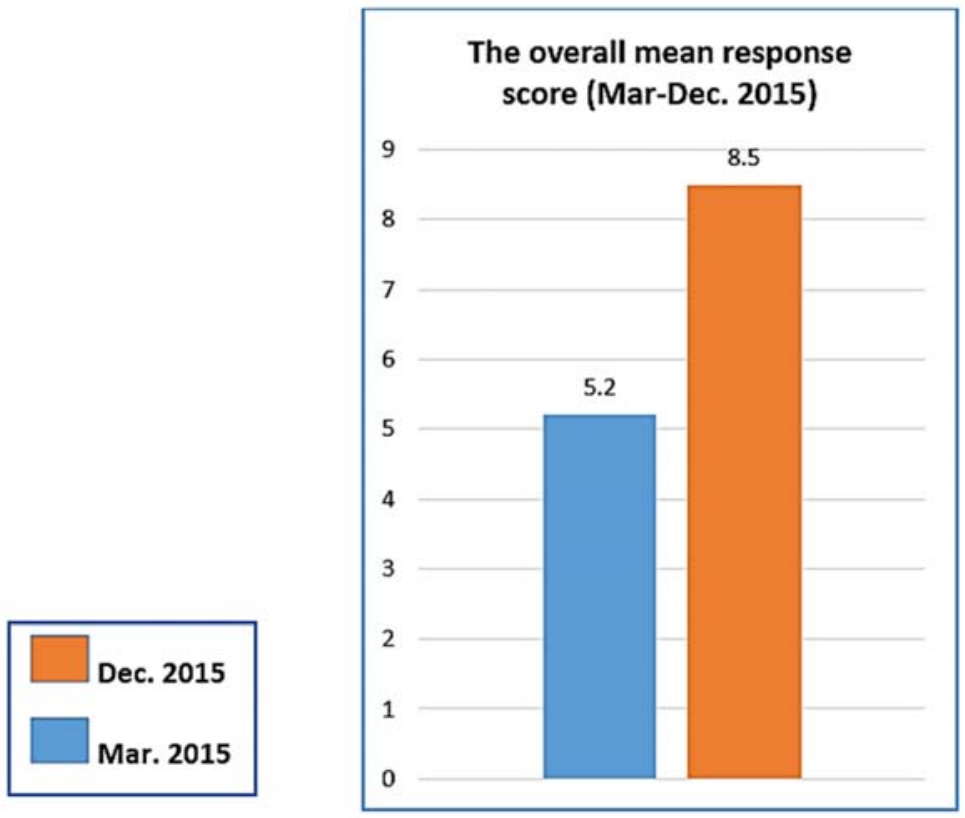

Figure 2. Comparison of mean standard scores

Eight items in particular reported significant item responses. These eight items are discussed in more detail below.

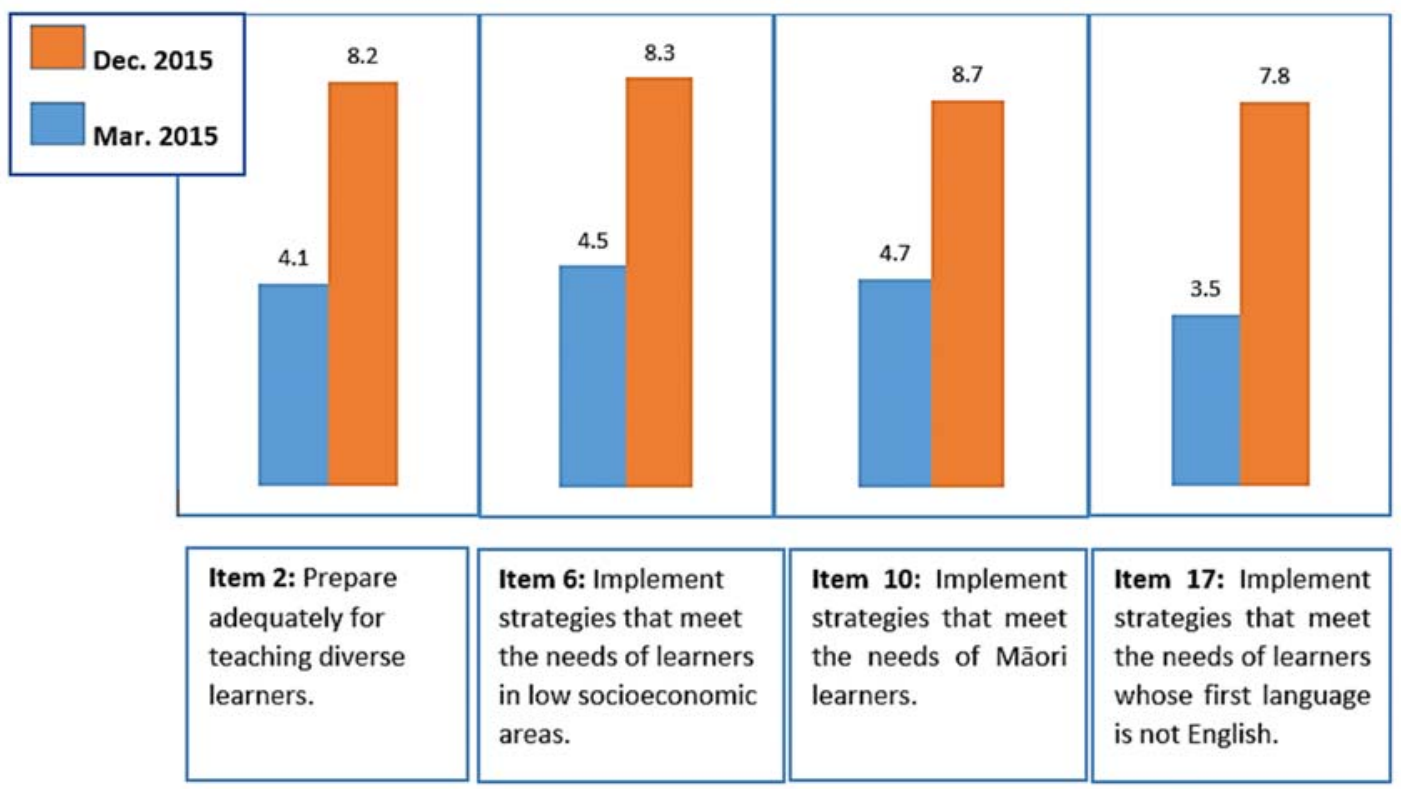

Figure 3. Comparison of responses for efficacy items 2, 6, 10, 17

Figure 3 above depicts respondents' responses for 4 of the 8 items. Items 2 and 17 scrutinise their views about the level of preparedness for teaching diverse learners and their beliefs that they can implement strategies to support learning for students whose first language is not English. The received mean response scores had a 4.1 and 4.3 increase, respectively, which 
are more than double the mean standard scores in March. In addition, items 6 and 10 examine respondents' efficacy beliefs to implement strategies that meet the needs of learners in low socio-economic areas and those of Māori learners, respectively. Similar to the findings above, the mean response scores had a 3.8 and 4 increase, respectively, which are almost double the mean response scores in March of the same year.

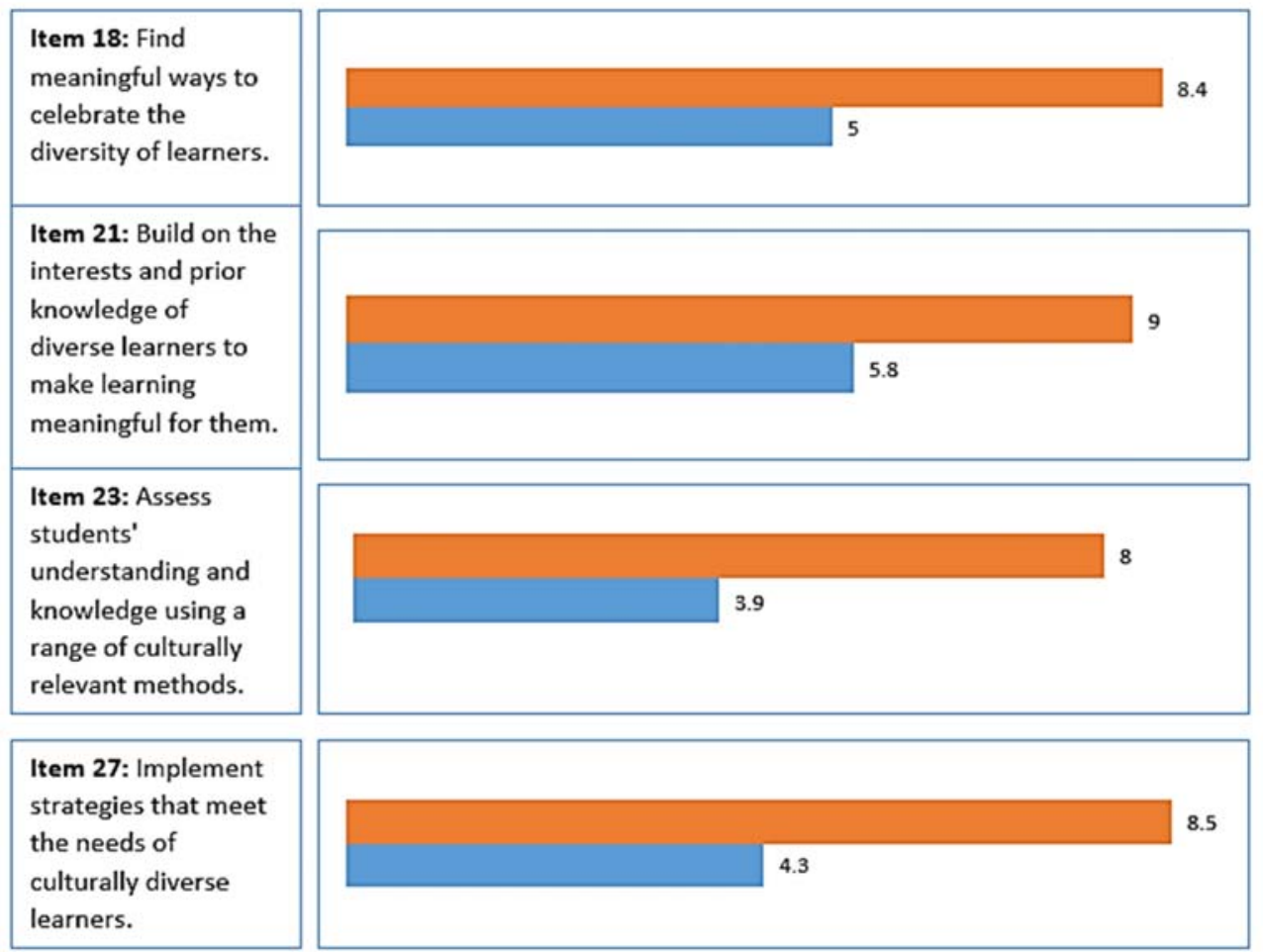

Figure 4. Comparison of responses for efficacy items 18, 21, 23, 27

Figure 4 above depicts responses on the other four significant items. Items 18 and 21 seek to investigate their perception of level of preparedness for finding meaningful ways to celebrate the diversity of learners and their efficacy beliefs to build on their interests and prior knowledge to make learning meaningful for these learners. The mean response scores had a 3.4 and 3.2 increase respectively, which is more than one third increase of the received mean response score in March. Items 23 and 27 seek to explore student teacher efficacy beliefs to assess students' understandings using a range of culturally relevant methods as well as the strategies they could implement to meet the needs of diverse learners. Similarly, the obtained mean response scores had a 3.8 and 4 increase, respectively, which are almost double those reported in March.

\section{Discussion}

The above results indicate evidence of the student teachers' significantly enhanced efficacy beliefs at completion of the Masters of Teaching and Learning. Whilst the survey does not ask respondents to indicate which specific programme design features worked to promote their enhanced efficacy beliefs, some interpretation is possible. Drawing on wider self-efficacy research, especially in relation to initial teacher education programmes, the following section 
discusses the eight items that reported the greatest change and proposes links with certain design features to explain these shifts.

Efficacy scores were shown to double for efficacy items 2, 6, 10, 17 - preparation for and implementation of strategies to meet the diverse learning needs of low socio-economic, Māori, Pasifika and ESOL students. The first and second design innovations of the programme that may explain these significant shifts are the prioritisation of continuous evidenceinformed and critical inquiry that focuses on the targeted exposure to the learning needs of priority learners. The 'teaching as inquiry' model (Aitken \& Sinnema, 2008) and the 'evidenceinformed professional learning cycles' (Timperley, 2011) both provided student teachers with the professional learning tools to "disrupt typical or habitual practices that may not be serving students as effectively as alternatives might... [and to] make defensible decisions on learning priorities for each of their learners" (Aitken \& Sinnema, 2008, pp. 18-21).

This focus on professional inquiry aligns with the Organisation for Economic Cooperation and Development's (2015) recommendations to "ensure that teachers and schools have the skills to collect, analyse and interpret data in order to support improved student outcomes" (p. 46). Engagement in this inquiry supported enactive mastery through the process of interrogating theoretical and research-based literature, which built outcome expectations that the culturally-responsive pedagogies they were using had previously been shown to support learning for priority learners. Opportunities for student teachers to engage collaboratively in their inquiries with their mentor teachers served to lift their efficacy expectations so that they could effectively enact these pedagogies. Furthermore, the use of an e-portfolio to store and reflect on artefacts from their inquiries provided evidence of impact of their changed teaching practice and gave an opportunity for their mentors and supervisors to provide verbal and written feedback. This acted as a potent form of social persuasion known to enhance efficacy beliefs.

The third design innovation that contributed to the conditions for successful mastery experiences was sustained clinical practice in two partner schools wherein students worked with priority learners to apply their university learning about cultural identity and culturally responsive pedagogies. As part of this explicit university teaching, as well as exposure to exemplary school practices that highlighted innovations to support priority learners, the student teachers were challenged to consider their own cultural identity and to engage with evidence about what was known to best support priority learners. Further, the programme's Graduate Profile was based on The Effective Teaching Profile (Bishop \& Berryman, 2009), Tataiako (Ministry of Education, 2011), and The Pasifika Education Plan (Ministry of Education, 2013b). The student teachers were required to demonstrate competency in these areas as part of their formative and summative assessment tasks. This targeted assessment enabled them to learn about and to respect their culturally diverse students' history, tikanga, and worldviews.

The fourth design innovation of the initial teacher education programme to support mastery teaching experiences with priority learners was the requirement for student teachers to engage in a community placement that provided experiences to build understanding and empathy for the values and practices of families and cultures different to their own (Bishop \& Berryman, 2006). This community service learning provided exposure to the worlds of their priority learners and was often confronting for student teachers. Their feelings of dissonance led to challenged assumptions and new frames of reference against which better informed judgments were made about priority learners and other marginalised groups (Timperley, 2011). These deepened understandings of diversity and equity were drawn upon in their 
clinical practice (Eyler, Giles, Stenson, \& Gray, 2001), serving to reduce instances of deficit theorising. The fifth design innovation, personalised learning, and its triadic framework of mentoring and supervisory support, further maximised the opportunity for mastery of complex teaching skills and pedagogical content knowledge.

Four other efficacy items, 18,21, 23, and 27, showed a near doubling of efficacy beliefs to: celebrating diverse learners; building on their prior interests and knowledge; using culturally relevant assessments; and implementing strategies to meet their needs. The three programme design features described above will have contributed to these significant efficacy shifts; however, a fourth main design feature - that of positioning the university programme within a strong and sustained partnership with local schools - may also explain the efficacy shifts. These sustained relationships between the sectors began in the codevelopment of the programme and ensured professional connections and shared values and understandings, important for high-performing initial teacher education programmes (Cochran-Smith, 2003). This university-school partnership created clinical settings that ensured a theory, research and practice nexus, and overcame the common problem articulated by Darling-Hammond (2006) wherein "the clinical side of teacher education has been fairly haphazard with ... little connection to university work" (p. 308).

Importantly, the clinical placement and its close interactions between lead mentor teachers, mentor teachers and the university supervisors provided multiple opportunities for enactive and vicarious mastery of skills to implement high leverage pedagogies and social persuasion through exemplary mentoring and close supervision. Both the university supervisor and mentor teachers played a vital role in providing feedback for their next steps in learning, which guided and encouraged their growing capabilities. Such social persuasion is most fruitful within trusting mentoring relationships (Grudnoff, 2011). The value of high quality mentors raises the issue of ensuring the professional preparation for mentors working in these university-school partnerships (Sewell, Hansen, \& Weir, 2017). Student teachers are more likely to achieve success leading to higher levels of efficacy in their teaching practice within such supportive and high quality clinical settings.

Finally, we consider the sources of efficacy information derived from programme features that led to student teachers' reported positive psychological responses as they learned to teach. The programme emphasised caring relationships, ongoing professional support within a community of learners, and the provision of stress-management tools to help build teacher resilience for the complex demands of teaching. These social features have all been shown in research to enhance learning and efficacy beliefs (Mansfield, Beltman, Price, \& McConney, 2012; Noddings, 2005; Sewell, St George, \& Cullen, 2013). When teachers experience the trust and sense of belonging to the profession that support the building of resilience through successfully adapting their practice, their positive physiological responses are interpreted as having high teacher efficacy.

The importance of creating positive psychological responses raises the issue of carefully selecting candidates into the profession who have the dispositions for teaching (O'Neill, Hansen, \& Lewis, 2014). These dispositions include strong relational skills, and a robust sense of identity and integrity (Palmer, 2007), as well as confidence, vitality and a passion for teaching. Such candidates are more likely to feel positive physiological responses, which, in turn, feed positive efficacy beliefs.

Whilst we have not yet conducted comparative analyses with other initial teacher education programmes, an external evaluation of the pilot programme commissioned by the Ministry of Education indicated similar positive patterns. Respondents from the 2015 cohort 
$(n=13)$ to the external survey reported that they felt well (30\%)-very well (70\%) prepared "to use evidence to inform their teaching" and "plan engaging experiences appropriate to individual learners' needs." Although not so overwhelmingly positive, they reported feeling well (60\%)-very well (30\%) prepared to effectively engage with Māori learners, Pasifika learners, and learners with special education needs. Most notably, $90 \%$ reported that they believed they could "critically reflect on their own teaching and learning" very well with the further $10 \%$ reporting they could do this well. Although we acknowledge the limitations of such a small sample, it did provide further evidence of student teacher confidence in their learning and preparedness in this pilot programme.

\section{Conclusion}

The teaching profession plays an integral role in shaping the next generation of New Zealand citizens. Initial teacher education providers share in this responsibility, most especially when it comes to preparing teachers who have the requisite adaptive expertise for our increasingly diverse classrooms and believe themselves capable of lifting achievement for each learner in their classrooms. The results from this study indicate that all 23 student teachers in the Masters of Teaching and Learning experienced significant increases in their self-efficacy beliefs to teach diverse student groups. Whilst it is inappropriate to draw direct correlations, it is our contention that the focused design features of the programme contributed to the increased student teacher efficacy. The study also points to the usefulness of having a measure that can evidence increases in student teacher efficacy and achievement in relation to graduate profiles. These findings deserve further attention, specifically the gathering of student teacher perspectives on aspects of the programme to which they attribute their raised efficacy beliefs. Such detail would be useful to teacher educators as they revise and refine initial teacher education programmes for the future. Furthermore, ongoing qualitative research also needs to be conducted to ascertain the durability of these enhanced efficacy beliefs in their first year of full-time teaching and beyond. In such ways, teacher educators need to consistently inquire into their practice to ensure optimum opportunities and experiences are provided for student teachers to flourish and be capable of promoting educational equity for all learners.

\section{References}

Aitken, G., \& Sinnema, C. (2008). Effective pedagogy in social sciences/tikanga ā iwi: Best evidence synthesis iteration (BES). Retrieved from https://www.educationcounts.govt.nz/publications/series/2515/32879/35263

Bandura, A. (1977a). Self-efficacy: Toward a unifying theory of behavioral change. Psychological Review, 84, 191-215.

Bandura, A, (1977b). Social learning theory. Englewood Cliffs, NJ: Prentice-Hall.

Bandura, A. (1997). Self-efficacy: The exercise of control. New York, NY: Freeman.

Bandura, A. (2006). Guide for constructing self-efficacy scales. In T. Urdan \& F. Pajares (Eds.), Self-efficacy beliefs of adolescents (pp. 307-337). Greenwich: Information Age.

Bishop, R., \& Berryman, M. (2006). Culture speaks: Cultural relationships and classroom learning. Wellington: Huia Press. 
Bishop, R., \& Berryman, M. (2009). Te Kotahitanga effective teaching profile, Set, 2, 27-33.

Bishop, R., Berryman, M., Cavangh, T., \& Teddy, L. (2009). Te Kotahitanga: Addressing educational disparities facing Māori students in New Zealand. Teaching and Teacher Education, 25, 734-742.

Cinici, A. (2016). Pre-service teachers' science teaching self-efficacy beliefs: The influence of a collaborative peer microteaching program. Mentoring and Tutoring: Partnership in Learning, 24(3), 228-249.

Cochran-Smith, M. (2003). Learning and unlearning: The education of teacher educators. Teaching and Teacher Education, 19, 5-28. doi:10.1016/S0742-051X(02)00091-4

Cochran-Smith, M., Ell, F., Grudnoff, L., Haigh, M., Hill, M, \& Ludlow, L. (2016). Initial teacher education: What does it take to put equity at the center? Teaching and Teacher Education, 57, 67-78.

Connor, L. (2013). Meeting the needs of diverse learners in New Zealand. Preventing School Failure: Alternative Education for Children and Youth, 57(3) 157-161. http://dx.doi.org/10.1080/1045988X.2013.795927

Darling-Hammond, L. (2006). Constructing $21^{\text {st }}$ century teacher education. Journal of Teacher Education, 57(3) 300-314. doi:10.1177/0022487105285962

Education Council. (2017, July). Strategic options for developing future oriented initial teacher education. Discussion Paper.

Education Review Office. (2012). Improving education outcomes for Pacific learners. Retrieved from http://www.ero.govt.nz/National-Reports/Improving-EducationOutcomes-forPacific-Learners-May-2012.

Eyler, J., Giles, D., Stenson, C., \& Gray, C. (2001). At a glance: What we know about the effects of service-learning on college students, faculty, institutions and communities, 1993-2000. Retrieved from http://www.compact.org/wp-content/uploads/resources/ downloads/aag. pdf.

Feiman-Nemser, S. (2001). From preparation to practice: Designing a continuum to strengthen and sustain teaching. Teachers College Record, 103, 1013-1055.

Filatov, K., \& Pill, S. (2015). The relationship between university learning experiences and English teaching self-efficacy: Perspectives of five final pre-service English teachers. Australian Journal of Teacher Education, 40(6), 33-59.

Florian, L. (2009). Preparing teachers to work in 'schools for all'. Teaching and Teacher Education, 25(4), 533-534.

Gibbs, C. (2002, December). Cultural efficacy: Implications for teachers and teacher education. A paper presented to the New Zealand Association for Research in Education Conference, Palmerston North, NZ.

Goddard, R. D., Hoy, W. K., \& Woolfolk Hoy (2000). Collective teacher efficacy: Its meaning, measure and impact on student achievement. American Journal of Educational Research, 37, 479-507.

Grudnoff, L. (2011). Rethinking the practicum: Limitations and possibilities. Asia-Pacific Journal of Teacher Education, 39(3), 223-234. doi:10.1080/1359866X.2011.588308

Hansen, S., Harworth, P., \& McLaughlin, T (in press). Student teacher efficacy with culturally linguistically and socioeconomically diverse learners. Journal of Education for Teachers.

Kaur, B. (2012). Equity and social justice in teaching and teacher education. Teaching and Teacher Education, 28, 485-492. 
Mansfield, C., Beltman, S., Price, A., \& McConney, A. (2012). Don't sweat the small stuff: Understanding teacher resilience at the chalkface. Teaching and Teacher Education, 28(3), 357-367.

Ministry of Education. (2011). Tataiako. Wellington, NZ: Learning Media.

Ministry of Education. (2013a). Quality teaching agenda. Retrieved from https://education.govt.nz/framework/main.php/specific-initiatives/lifting-thequality-of-initial-teacher-education-provision

Ministry of Education. (2013b). The Pasifika education plan. Retrieved from https://education.govt.nz/framework/main.php/overall-strategies-andpolicies/pasifika-education-plan-2013-2017/?url=/ministry-of-education/overallstrategies-and-policies/pasifika-education-plan-2013-2017/

Organisation for Economic Co-operation and Development. (2015). Evaluation at a glance: Priority learners in New Zealand schools. Retrieved from http://www.oecd.org/edu/education-at-a-glance-2015.htm

O'Neill, J., Hansen, S., \& Lewis, E. (2014). Dispositions to teach: Review and synthesis of current components and applications, and evidence of impact (Report to the Schooling Policy Group). Wellington, NZ: Ministry of Education. Retrieved from https://www.education.govt.nz/assets/Uploads/DispositionsReportFinal100914.pdf

O’Neill, J., Hansen, S., Rawlins, P., \& Donaldson, J. (2013). Editorial introduction: Reclaiming and reframing a national voice for teacher education. Special Edition: Reclaiming and reframing teacher education in Aotearoa New Zealand. Waikato Journal of Education, 18(1), 3-6.

Noddings, N. (2005). The challenge to care in schools: An alternative approach to education. New York, NY: Teachers College Press.

Palmer, P. J. (2007). The courage to teach: Exploring the inner landscape of a teacher's life. San Francisco, CA: Jossey-Bass.

Ross, J. A. (1998). Antecedents and consequences of teacher efficacy. Advances in Research and Teaching, 7, 49-74.

Sewell, A. M., Hansen S. E., \& Weir, K. M. (2017). Enhancing the capabilities of associate teachers in the practicum: A New Zealand case study. New Zealand Journal of Educational Studies, 52, 21-39. doi:10.1007/s40841-017-0078-z

Sewell, A. M., St George, A., \& Cullen, J. (2013). The distinctive features of joint participation in a community of learners. Teaching and Teacher Education, 31, 46-55.

Timperley, H. (2011). Realizing the power of professional learning. Maidenhead: McGraw-Hill.

Tolley, A. (2010). In the Education Workforce Advisory Group. Retrieved from http://www.ieag.org.nz/documents/DiscussionDocumentPDF.pdf

Tschannen-Moran, M., \& Woolfolk Hoy, A. (1998). Teacher efficacy: Its meaning and measure. Review of Educational Research, 68, 202-248.

Tschannen-Moran, M., \& Woolfolk Hoy, A. (2001). Teacher efficacy: Capturing an elusive construct. Teaching and Teacher Education, 17(7), 783-805.

Williams, J. (2014). Teacher educator professional learning in the third space: Implications for identity and practice. Journal of Teacher Education, 65(4), 315-326. 
Sally Hansen is the Director of Professional Education Programmes at the Institute of Education, Massey University. Her research interests include building teacher resilience and self-efficacy, and developing school-university partnerships.

Email: S.E.Hansen@massey.ac.nz

Alison Sewell is a teacher educator and leader of the MTchgLn Programme at the Institute of Education, Massey University. Her research interests include developing sociocultural pedagogies, teachers' professional learning and building school-university partnerships.

Email: A.M.Sewell@massey.ac.nz

Sarojinie Fernando is a Research Officer at the Institute of Education. Her research interests include teacher self-efficacy and students' learning mathematics in classroom settings.

Email: S.Fernando1@massey.ac.nz

Abdelhamid Safa is a PhD student in the Institute of Education at Massey University. He holds an MA in Applied Linguistics \& TESOL from the University of Leicester.

Email: A.Safa@massey.ac.nz 